\title{
Predicting the Probability of Divorce Occurrence by the Index of Family Function
}

\author{
Nazanin Mahdinia $^{1}$, Dr Mohammad Ghamari ${ }^{2}$
}

\section{ABSTRACT}

This study is designed to analyze the predicting the probability of divorce in women through family function among married student from Azad Abhar University. This study is base on correlation and randomly sampled. The targeted population for this study were 200 voluntary participant of married female student. This study includes family functional survey, Mac Master (FAD), and the instability of marriage (Probability of divorce) survey that data collected from the surveys were analyzed by Pearson correlation coefficient, and Multiple regression analysis. Findings from this study shows that there is a relation between family functions and probability of divorce.

\section{Keywords: Family Functions, Occurrence Of Divorce}

Divorce is one of the crises that in most cases jeopardize the mental health of the family. With regard to various kinds of divorce including emotional, psychological, economic, social, legal, parental and their respective damages that threatens the family, conflict and divorce and issues related to that are of significant importance. But more important than that is the effects and consequences that divorce exerts on society and that it is together with disintegration of the family's foundation with short-term and long-term financial, legal, individual, and social effects for children and adults. Research has shown that the function of family is effective in creation of marital conflicts. Moreover, the evidences represent that the quality of family relationships is different in divorcing and un-divorcing families as such that more conflicts are observed in divorcing families (Lindesey, colwell, frubull \&Mackinnon, Lewis, 2006).

Reaching a healthy society clearly requires health of the family and reaching a healthy family requires its people to have mental health and appropriate relationships with each other; therefore, ensuring the health of the members of the family and their relationships undoubtedly exert

\footnotetext{
${ }^{1}$ M.A In Counseling Psychology, Islamic Azad University Abhar Branch, Abhar, Iran

${ }^{2}$ Department of psychology, Abhar branch, Islamic Azad University, Abhar, Iran

*Responding Author

(C) 2016 I N Mahdinia, M Ghamari; licensee IJIP. This is an Open Access Research distributed under the terms of the Creative Commons Attribution License (http://creativecommons.org/licenses/by/2.0), which permits unrestricted use, distribution, and reproduction in any Medium, provided the original work is properly cited.
} 


\section{Predicting the Probability of Divorce Occurrence by the Index of Family Function}

positive effects on society and it can be said that family function has direct and significant effect on the function of society.

In this study family function is investigated from various perspectives like Mc Master's perspective. In Mc Master's perspective, family function involves seven dimensions that are as follows: problem solving dimension, communications, roles, emotional responsiveness, emotional dependency, control of behavior and general function that to improve and increase the functional level this study aims to determine prediction of possibility of occurrence of divorce in women by the index of family function.

\section{Ethical Principles}

As it is known, the Men who have sex with men (MSM) are the minority, therefore, they can be considered as the vulnerable members of the society. Further, obtaining the written informed consent is more important for this population. It means that, the possibility of "being informed" or "acting based on the will" is significantly less among the vulnerable members of the society. In this study, the informed consent was obtained without coercion, threat, enticement and seduction and their decision to refuse or accept to participate in the study were respected. It was also tried that the research methods do not contradict with the religious and cultural principles of the participants and the participants were respected in all stages of design, implementation and reporting in terms of human dignity, respect and protection of their physical and mental integrity so that conducting the research would not delay in the process of medical care for the participants.

\section{METHODOLOGY}

This study was a kind of survey and the methodology used was descriptive and of correlational type. The statistical community of this study was all the married student women that were busy studying in Azad university of Abhar in second term of 1392-1393. In this study 200 people were selected from students in dormitory by random sampling. Questionnaires of this study were extent of instability of marriage (divorce) with Corn bache's alpha reliability of $93 \%$ and validity of 70\% and Mc Master's questionnaire (FAD) with Corn Bache's alpha reliability index of 83\% and subscales of $90 \%$ that in another study for changing the internal reliability of this scale, Schtain (2001) estimated the minimum alpha index of scales as $75 \%$.

\section{Statistical analysis}

First descriptive statistics was used and the data of the research were brought in respective tables and in the second part statistical analysis was done. In order to analyze the data of the research, with respect to nature of it, Pearson correlation test and multivariable regression analysis was used. 


\section{RESULTS}

\section{Table1. Descriptive index of the research variables}

\begin{tabular}{|c|c|c|c|c|c|c|}
\hline \multicolumn{2}{|c|}{$\begin{array}{l}\text { Statistical } \\
\text { indices of the variable }\end{array}$} & number & mean & SD & Minimum & Maximum \\
\hline \multirow{8}{*}{ Family function } & Problem solving & 180 & 16.27 & 4.26 & 9 & 24 \\
\hline & communications & 180 & 19.87 & 5.03 & 8 & 27 \\
\hline & roles & 180 & 25.67 & 6.69 & 11 & 36 \\
\hline & Emotional support & 180 & 18.00 & 5.54 & 7 & 26 \\
\hline & $\begin{array}{l}\text { Emotional } \\
\text { intercourse }\end{array}$ & 180 & 17.97 & 4.32 & 10 & 27 \\
\hline & $\begin{array}{l}\begin{array}{l}\text { Control of } \\
\text { behavior }\end{array} \\
\end{array}$ & 180 & 17.80 & 6.88 & 10 & 33 \\
\hline & General function & 180 & 37.13 & 6.90 & 25 & 50 \\
\hline & $\begin{array}{l}\text { Family } \\
\text { function(total } \\
\text { score) }\end{array}$ & 180 & 152.70 & 28.65 & 101 & 207 \\
\hline $\begin{array}{l}\text { Instability of } \\
\text { marriage(possibility } \\
\text { of occurrence of } \\
\text { divorce) }\end{array}$ & & 180 & 25.30 & 6.13 & 15 & 39 \\
\hline
\end{tabular}

Table 1 represents descriptive indices in research variables that among them the mean has central tendency and standard deviation has tendency toward the distribution of scores.

Table 2. Normality test of the distribution

\begin{tabular}{|l|l|l|l|}
\hline \multicolumn{2}{|l|}{ Statistical indices of the variable } & $\begin{array}{l}\text { Kolmogorov } \\
\text { Smirnov Z }\end{array}$ & Significant level \\
\hline \multirow{4}{*}{ Family function } & Problem solving & 1.19 & 0.11 \\
\cline { 2 - 4 } & communications & 0.94 & 0.33 \\
\cline { 2 - 4 } & roles & 1.28 & 0.07 \\
\cline { 2 - 4 } & Emotional support & 1.29 & 0.07 \\
\cline { 2 - 4 } & Emotional intercourse & & 0.46 \\
\cline { 2 - 4 } & Control of behavior & 0.94 & 0.33 \\
\cline { 2 - 4 } & General function & 1.23 & 0.09 \\
\cline { 2 - 4 } & $\begin{array}{l}\text { Family function(total } \\
\text { score) }\end{array}$ & 1.11 & 0.46 \\
\hline
\end{tabular}

(C) The International Journal of Indian Psychology, ISSN 2348-5396 (e) | ISSN: 2349-3429 (p) | 113 


\section{Predicting the Probability of Divorce Occurrence by the Index of Family Function}

As it can be inferred from the findings of the table 2, since the obtained significant level in K-S for the respective variables of the study is more than criterion of 0.05 , therefore it can be said that the distribution of the variables in statistical sample has normal distribution. Therefore the research hypotheses are examined by parametric tests of Pearson correlation test and regression analysis.

Moreover the normality of the distribution of the variables is examined by appropriate statistical test.

Table3. The results of Pearson correlation coefficient between variables of family function and possibility of occurrence of divorce

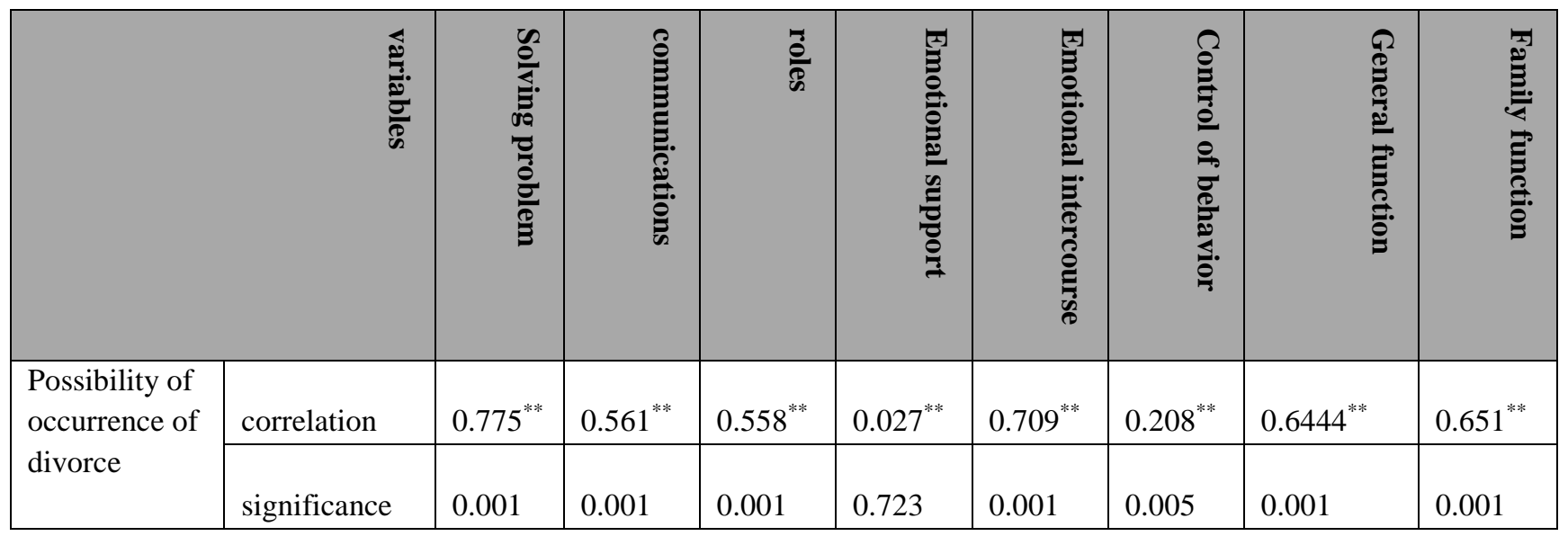

**significant correlation at the level of 0.05

As the results of table 3 shows, through Pearson correlation coefficient, there is a significant relationship between the variables of solving problem, communications, roles, emotional intercourse, control of behavior, general function, total score of family function and possibility of occurrence of divorce in students at the level of 0.01 . Moreover since the relationship is positive and significant, it can be concluded that however the individuals take higher scores in family function variable and have inappropriate conditions( note that in the questionnaire of family function, high score represents inappropriate condition and poor function of the family and vice versa), the possibility of divorce among them is more and vice versa.

In the following sections we investigate the prediction of possibility of occurrence of divorce:

Table4: The results of regression coefficients and coefficients of estimation

\begin{tabular}{|l|l|l|c|}
\hline variable & $\begin{array}{l}\text { Multiple correlation } \\
\mathbf{R}\end{array}$ & $\begin{array}{l}\text { Coefficient of } \\
\text { determination } \mathbf{R}^{2}\end{array}$ & $\begin{array}{l}\text { Adjusted coefficient } \\
\text { of determination } \mathbf{R}^{2}\end{array}$ \\
\hline $\begin{array}{l}\text { Multi-variable } \\
\text { regression }\end{array}$ & 0.890 & 0.791 & 0.783 \\
\hline
\end{tabular}

(C) The International Journal of Indian Psychology, ISSN 2348-5396 (e)| ISSN: 2349-3429 (p) | 114 
As the results of regression analysis shows the extent of multiple-regression coefficient among the variables family function and its subscales and possibility of occurrence of divorce is 0.890 . Moreover the subscales of family function can predict 79.10 percent of variances related to variable of possibility of occurrence of divorce. To determine the significance of these variances, variance analysis was used.

Table5. Regression analysis of dependent variable of possibility of occurrence of divorce

\begin{tabular}{|l|l|l|l|l|l|l|}
\hline Model & $\begin{array}{l}\text { Sources of } \\
\text { variance }\end{array}$ & $\begin{array}{l}\text { Aggregates } \\
\text { of square }\end{array}$ & $\begin{array}{l}\text { Degree } \\
\text { of } \\
\text { freedom }\end{array}$ & $\begin{array}{l}\text { Mean of } \\
\text { squares }\end{array}$ & F & $\begin{array}{l}\text { Significant } \\
\text { level( p ) }\end{array}$ \\
\hline \multirow{2}{*}{$\begin{array}{l}\text { Multivariable } \\
\text { regression }\end{array}$} & regression & 5328.74 & 7 & 761.249 & 93.188 & \multirow{2}{*}{0.0001} \\
\cline { 2 - 5 } & leftover & 1405.06 & 172 & 8.169 & & \\
\cline { 2 - 5 } & Total & 6733.8 & 179 & & & \\
\hline
\end{tabular}

Regarding table 5, the results of regression analysis shows that amount of $\mathrm{F}=93.18$ are significant at the level of 0.99 .

Table6. The results related to standard and non-standard coefficients in the research model.

\begin{tabular}{|c|c|c|c|c|c|}
\hline \multirow{2}{*}{ Levels } & \multicolumn{2}{|c|}{ Non-standard coefficient } & \multirow{2}{*}{$\begin{array}{l}\text { Standard } \\
\text { coefficient }\end{array}$} & \multirow[b]{2}{*}{$\mathbf{t}$} & \multirow[b]{2}{*}{$\begin{array}{l}\text { Levels of } \\
\text { significance } \\
\text { (p) }\end{array}$} \\
\hline & $\mathbf{B}$ & $\begin{array}{l}\text { Extent of } \\
\text { Error }\end{array}$ & & & \\
\hline Stable amount & 41.153 & 1.535 & & 26.803 & 0.0001 \\
\hline Solving problem & 0.849 & 0.105 & 0.59 & 8.073 & 0.0001 \\
\hline communications & 0.231 & 0.079 & 0.19 & 2.912 & 0.004 \\
\hline roles & 0.21 & 0.066 & 0.23 & 3.193 & 0.002 \\
\hline Emotional support & 0.528 & 0.05 & 0.477 & 10.599 & 0.0001 \\
\hline $\begin{array}{l}\text { Emotional } \\
\text { intercourse }\end{array}$ & 0.563 & 0.134 & 0.396 & 4.208 & 0.0001 \\
\hline Control of behavior & 0.053 & 0.039 & 0.059 & 1.352 & 0.178 \\
\hline General function & 0.042 & 0.058 & 0.048 & 0.728 & 0.467 \\
\hline
\end{tabular}

The possibility of occurrence of divorce (dependent variable)

As it was shown in table 6 variables of solving problem, communications, roles, emotional intercourse and emotional support in level of 0.01 has significant relationship with variable of possibility of occurrence of divorce because the calculated significant level is lower than criterion amount of 0.01 and the obtained $t$ is also meaningful. The results of regression analysis

(C) The International Journal of Indian Psychology, ISSN 2348-5396 (e)| ISSN: 2349-3429 (p) | 115 


\section{Predicting the Probability of Divorce Occurrence by the Index of Family Function}

shows that among the independent variables, solving problem, communications, roles, emotional intercourse and emotional support can positively predict variable of possibility of occurrence of divorce with reliability of $99 \%$ among students. Therefore the research hypothesis is confirmed and null hypothesis is rejected.

\section{DISCUSSION AND CONCLUSION}

This research represented that there is positively significant relationship between the variables of family function and variable of probability of occurrence of divorce among students and taking higher scores in the variable of family function represents inappropriate situation of the family and as the result the probability of occurrence of divorce among them is more. The obtained results from this study is conforming with the results of research of Rahimi Nejad, Paknejad(1393),Chaboki(1392), Bakhshipour et al.(1391), Mohammadifar, Talebi, Seyyed Tabatabayee(1389).

Therefore the factors of family function that includes solving problem, communications, roles, emotional responsiveness, emotional intercourse, control of behavior and general function are positive answer to solve conflicts especially when the members need help. Through examining the findings of this research we reached to this conclusion that with reinforcing and addressing each of these factors we can improve the family function and in reverse the weakness of each of these factors leads to decreasing of quality of family function (Erion et al.,translated by Dehghani and Abbasi (1391). This is because family function is sharing effort to produce and maintain balance in the family and a family with appropriate function is like a game system that its members are connected emotionally, however to expand individual identity they should be encouraged to create an atmosphere full of love and un-doubtable acceptance that results in lower levels of family conflicts. Those families who have full range of expression of feelings, from happiness to sadness and anger, are healthy and those families which have problem in expression of their feelings and have inflexible patterns of emotions are considered unhealthy because a healthy family is a family in which couples can discuss important issues of themselves and welcome any positive change (Right and Li Hey,1380). According to Fishro Sprange(1978) the sources showed that the intervention of the family function can be effective strategy to balance family discipline in a form that members know in critical time and for solving problems ahead and pressures that creates and increases the intention of divorce like occupational pressures, familial pressures, cognitive misunderstanding, sexual issues, monotony in life, inattention to family issues, not knowing fundamental needs of men and women, mental and physical bore, role of personality, emotional and mental disorders which issues to be discussed and how to discuss them and to use which realistic plans and not to go far or less in cognitive and emotional encountering with issues. This is very important and thus the extent of their desire and tendency to divorce and separation that according to scholars and sociologists is one of the complicated and multidimensional social and familial disorders is reduced. 


\section{Predicting the Probability of Divorce Occurrence by the Index of Family Function}

With respect to conducted studies when the family function and (its comprising factors) is in appropriate and adjusted level, the extent of desire to divorce and tendency of couples to separation is reduced and vice versa and this is the result of findings of present study.

\section{Acknowledgments}

The author appreciates all those who participated in the study and helped to facilitate the research process.

\section{Conflict of Interests}

The author declared no conflict of interests.

\section{REFERENCES}

Bakhshipour, Babolllah; Asadi, Masoud; Kiani, Ahmadreza; Shiralipour, Asghar \& Ahmaddoust, Hosein(1391). The relationship of family function with marital conflicts of couples on the verge of divorce. knowledge and research in applied psychology,13(2), 10-19.

Balestrnoa , A .Ciardib . C. Mamminia. C. (2013) . On the causes and consequences of divorce . The journal of socio- economics.

Beaulieu .M. Massner . S. (2010) . Assessing changes in the Effect of divorce rates on homicide criminology \& penology . 24 .(52) .

Bowen Center for the Study of the Family (2009). Triangles. Retrieved on September 19, 2009.from http://www.thebowencenter.org

Chaboki, Ommolbanin.(1392). Intergeneration study of the relationship of attitude toward divorce and family functions in women of Tehran. Studies of woman and family, 1(1), 159-185.

Eldar-Avdan., Haj-Yahia, M. \& Grinbam, W. (2009). Divorces is a part of my life...resilience, survival, and vulnerability: Young adults' perception of the implications of parental divorce. Journal of Marital and Family Therapy.

Goldenberg, H. \& Goldenberg, I. (2004). Family therapy: An overview. Belmont, CA: Thomson.

Gottman.J.m\& Levenson . R.W. (2002) .A two - factor model for predicting when a couple will divorce : Exploratory analysis using 14 year longitudinal data family process, 14, 83-96.

Hammond, R., \& Nichols, M. (2008). How collaborative is structural family therapy? Family.

Hewitt Belinda (2008). Marriage breakdown in Australia: social correlates, gender and initiator status . Social Policy Research. No 33.

Kalmijn , M \& Poortman, A. (2006). His or her divorce? The gendered nature of divorce and determinants . European socialogical review. Vol 2-22.pp.

Lindsey, E. W., Colwell, M. J., Frabutt, J. M \& MacKinnon-Lewis, C. (2006). Family conflict in divorced and non-divorced families: Possible consequences for boys' mutual friendship and friendship quality. Journal of Social and Personal Relationships, 23, 45-63. 


\section{Predicting the Probability of Divorce Occurrence by the Index of Family Function}

Mohammadifar, Mohammad Ali, Talebi Abolfazl, Tabatabyee Seyyed Mousa (1389). The effect of teaching of life skills on family function in women with addicted husband, periodical of addiction research, number 16, pp. 25-40

Nichols, M. (2009). The essentials of family therapy, Boston, Massachusetts: Person Education, Inc.

Poortman.A (2005).woman's work \& divorce: Amatter of anticipation. A research note .European sociological review,21.pp.301-309.

Rahimi Nejad, Abbas, Pak Nejad, Mohsen (1393), the relationship of family function and psychological needs with mental health of adolescents, the periodical of family research, number 37, page 99.

Roberts, J. (2005). Trans parency and self-disclosure in family therapy: Dangers and possibilities. Family Process, 44(1), 45-63. Retrieved October 11, 2009, from Research Library. (Document ID: 810928731).

Van Leeuwen, M.C., post, W.M., Van Asbeck, W.F., Vander Woude, H.V., Groot, S. and Lindeman, E. (2010). Social support and Life satisfaction in spinal cord injury during and up to one year after inpatient rehabilitation. Journal of psychology,46, pp. 265-271.

Wallerstine J:Lewis,J : Packer R (2013).Mothers \& their children after divorce : report from a 25year longitudinal study . Psychoanalytic Psychology,30

Whitton S . Scott M.Stanley .t. Howard j . Markman C. Crisrine A .(2013) . Attitudes toward divorce, commitment \& divorce proneness in First Marriage \& Remarriages . journal of marriage \& family.75(2). 276-287.

How to cite this article: N Mahdinia, M Ghamari (2016), Predicting the Probability of Divorce Occurrence by the Index of Family Function, International Journal of Indian Psychology, Volume 3, Issue 4, No. 56, ISSN 2348-5396 (e), ISSN: 2349-3429 (p), DIP: 18.01.011/20160304, ISBN: 978-1-365-23992-2 